\title{
DINAMIKA MANAJEMEN PEMERINTAHAN DI INDONESIA
}

\author{
Samugyo Ibnu Redjo \\ Samugyo.ir@gmail.com

\section{Guru Besar Ilmu Pemerintahan \\ Universitas Padjadjaran}

\begin{abstract}
Abstrak
Manajemen pemerintahan sebagaimana tuntutan keberadaannya dan tuntutan Undang-undang tentang Pemerintahan Daerah, seyogyanya berubah sejalan dengan tuntutan globalisasi, pola-pola manajemen tradisional feodal diganti dengan pola modern yang demokratis. Hal itu paling tidak karena manajemen pemerintahan tidak dapat dilepaskan dari kepolitikan global, kepentingan nasional dan tentunya kepentingan regional serta kepentingan lokal. Pemahaman ini perlu ditekankan bagi manajemen pemerintahan di Daerah karena era global berarti pasar global, ekonomi global dan nilai-nilai global.

Dalam perkembangannya muncul pendapat bahwa pemerintah seharusnya berubah mengikuti perubahan ekonomi yang ada dan menjadikan pemerintahan yang memiliki kemampuan entrepreneur, sehingga gerak ekonomi dapat diikuti oleh pemerintah dan menyarankan agar pemerintah menerapkan sepuluh prinsip pemerintahan wirausaha (Osborne dan Gaebler 1992, juga Guillart dan Kelly, 1995). Selanjutnya Osborne dan Plastrik (1996) mengemukakan lima strategi (5 C's Strategy) sebagai implementasi lebih lanjut dari prinsip -reinventing government yang diajukan Osborne dan Gaebler.

Oleh karena itu, demokratisasi manajemen pemerintahan di Daerah merupakan faktor yang menentukan untuk keberlangsungan otonomi, sehingga partisipasi efektif dari seluruh lapisan masyarakat dapat berlangsung tanpa perbedaan prinsip satu dengan lainnya. Terselenggaranya manajemen pemerintahan yang demokratis menunjukkan bahwa elit politik pemerintahan memahami dan memiliki kemampuan untuk melaksanakan nilai-nilai demokrasi sebagaimana adanya, baik pada tataran kebijakan, tataran implementasi maupun pada tataran kultural yang mensyaratkan adanya mekanisme check and balances (saling kontrol dan saling mengimbangi) antara pemerintah dengan yang diperintah.
\end{abstract}

\section{Kata Kunci : Manajemen, Pemerintahan}

\section{Pendahuluan}

Manajemen pemerintahan sebagaimana tuntutan keberadaannya dan tuntutan Undang-undang tentang Pemerintahan Daerah, seyogyanya berubah sejalan dengan tuntutan globalisasi, pola-pola manajemen tradisional feodal diganti dengan pola modern yang demokratis. Hal itu paling tidak karena manajemen pemerintahan tidak 
dapat dilepaskan dari kepolitikan global, kepentingan nasional dan tentunya kepentingan regional serta kepentingan lokal. Pemahaman ini perlu ditekankan bagi manajemen pemerintahan di daerah karena era global berarti pasar global, ekonomi global dan nilai-nilai global.

Adapun kepentingan nasional bertumpu pada terjaminnya stabilitas negara, integrasi politik dan integrasi ekonomi, sedangkan kepentingan lokal diorientasikan pada terpenuhinya kenyamanan lingkungan lokal, yang meliputi kesejahteraan, stabilitas politik dan stabilitas ekonomi serta terjaganya lingkungan fisik maupun non fisik. Dengan demikian perlu adanya perubahan manajemen yang berbasis akuntabilitas, transparan, keterbukaan dan didasarkan pada ketegasan dalam penegakan hukum perlu dilakukan. Namun demikian untuk terjadinya perubahan manajemen tersebut, maka perlu lebih dipahami tentang demokratisasi pada pemerintahan di Daerah.

\section{Demokratisasi Manajemen Pemerintahan di Daerah}

Keberadaan pemerintah pada dasarnya disebabkan banyak faktor, salah satunya oleh adanya perjanjian sosial (social contract). Perjanjian sosial ini berimplikasi pada dua fungsi utama pemerintah. Implikasi tersebut adalah: Pertama, bahwa para pemimpin yang terpilih diantara mereka (yang selanjutnya disebut dengan -pemerintah ), menerima kekuasaan dari rakyat untuk mengatur hal apapun yang berkenaan dengan upaya mewujudkan ketertiban dan kesejahteraan rakyat. Meskipun pemerintah telah menerima kekuasaan yang cukup besar, namun kedaulatan tetap dipegang oleh rakyat. Oleh karena itu, pada waktu-waktu tertentu, kekuasaan ini harus dipertanggungjawabkan kembali kepada rakyat. Disini terlihat kedudukan rakyat secara politis lebih tinggi dari pemerintah. 
Kedua, bahwa pemerintah mengemban tugas-tugas yang begitu luas meliputi seluruh aspek kehidupan masyarakat. Meskipun pemerintah memiliki berbagai sumber daya untuk memenuhi kewajibannya, tetap saja tuntutan masyarakat akan selalu lebih tinggi dibanding dengan kemampuan pemerintah untuk memenuhinya. Kesenjangan antara tuntutan pelayanan masyarakat dengan kemampuan pemerintah inilah yang pada gilirannya menyebabkan munculnya gagasan pakar ilmu pemerintahan untuk memberikan -energy baru pada pemerintah antara lai adalah pendapat yang mengemukakan bahwa ditengah-tengah fenomena perubahan dunia, maka pemerintah perlu mengelola kreatifitas dan inovasi yang bersifat strategis dan perubahan itu sendiri (Bazelay, 1992).

Selain itu ada pendapat yang lebih jelas bahwa pemerintah seharusnya berubah mengikuti perubahan ekonomi yang ada dan menjadikan pemerintahan yang memiliki kemampuan entrepreneur, sehingga gerak ekonomi dapat diikuti oleh pemerintah dan menyarankan agar pemerintah menerapkan sepuluh prinsip pemerintahan wirausaha (Osborne dan Gaebler 1992, juga Guillart dan Kelly, 1995). Selanjutnya Osborne dan Plastrik (1996) mengemukakan lima strategi (5 C's Strategy) sebagai implementasi lebih lanjut dari prinsip -reinventing government yang diajukan Osborne dan Gaebler.

Dari pandangan diatas, maka manajemen pemerintahan harus mampu menciptakan nilai-nilai baru dalam rangka pelayanan kepada masyarakat atau memberikan nilai tambah (added value) terhadap jasa pelayanan yang telah ada sebelumnya.

Strategi seperti inilah yang antara lain disebut dengan Value Creation Management dalam Manajemen Pemerintahan. Pentingnya nilai tambah, bagi manajemen pemerintah berakibat pada pelayanan publik yang memuaskan sebagaimana perjanjian yang telah disepakati antara rakyat dengan pemerintah. 
Pada tataran ini, gagasan good governance memasuki wilayah pemerintahan, melalui kemampuannya untuk mengantisipasi dan memahami aspirasi masyarakat. Joseph Tusman (1989) menyatakan bahwa:-Governance not by the best among all of lus but by the best within each of us, yang maksudnya adalah bahwa kepemerintahan itu dilaksanakan sebaiknya bukan oleh orang-orang terbaik diantara aparatur negara, tetapi justru oleh kemampuan terbaik dari setiap individu aparatur negara yang bersangkutan. Hal ini merupakan konsekuensi dari manajemen pemerintahan dalam perencanaan, pengorganisasian, menggerakkan dan pengendalian kehidupan sosio ekonomi masyarakat guna pelayanan yang terukur, pemberdayaan yang dinamis dan pembangunan yang terkendali.

\section{Sinergitas dalam Manajemen Pemerintah di Daerah}

Untuk mengatasi hal tersebut, maka berkembanglah kebutuhan untuk menciptakan dan membangun kembali unit-unit birokrasi yang terdesentralisasi, hubungan kerjsama informal yang memberikan suatu suasana kondusif, sistem birokrasi yang didasarkan pada nilai-nilai kebersamaan (shared value) dan komitmen terhadap tujuan bersama. Hal ini sering disebut sebagai istilah budaya korporat (corporate culuture). Keterpaduan dan sinergi dalam manajemen budaya korporat itu ada dan muncul dalam pelayanan publik.

Berkembangnya manajemen pemerintahan, tidak dapat dilepaskan dari peran lingkungan karena pada dasarnya pada setiap fungsi manajemen interrelasi dan interkoneksi antara fungsi manajer dengan lingkungan. Keberadaan sistem tersebut merupakan rangkaian hubungan antara manajer pemerintahan dengan lingkungannya. 


\section{Mekanisme Manajemen Pemerintahan}

Ekstensi (perluasan) manajemen bersifat internal organisasional sekaligus eksternal organisasional dalam hal ini lingkungan. Pada tingkat internal persoalan utama adalah pada kualitas dan kapabilitas manajer untuk menggerakkan roda organisasi, dalam hal ini kemampuan manajer untuk mengkomunikasikan, memotivasi dan mempengaruhi serta menekankan loyalitas bawahan teradap pimpinan, sehingga anggota manajemen dapat bergerak dalam satu kesatuan yang sistemik. Dengan kata lain, fungsi manajemen pemerintahan dalam lingkup internal adalah menjaga keutuhan gerakan serta merorientasi terus menerus mengenai tujuan organisasi.

Sementara pada persoalan eksternal organisasional, maka hal itu lebih menunjuk pada entrepreneur sense/spirit dari manajer pemerintahan, yaitu dalam kerangka membangun kemitraan yang efektif dan saling menguntungkan antara organisasi publik dengan lingkungannya. Untuk itulah persoalan manajerial yang efektif tidak memungkinkan sifat-sifat parasitisme muncul, melainkan proses saling menghidupkan dan membesarkanlah (symbiosis mutualistis) yang ada. Dari sinilah muncul gagasan untuk demokratisasi manajemen pemerintahan, khususnya di Daerah sebagaimana tuntutan otonomi Daerah.

Demokratisasi manajemen pemerintahan di Daerah merupakan faktor yang menentukan untuk keberlangsungan otonomi, sehingga partisipasi efektif dari seluruh lapisan masyarakat dapat berlangsung tanpa perbedaan prinsip satu dengan lainnya. Terselenggaranya manajemen pemerintahan yang demokratis menunjukkan bahwa elit politik pemerintahan memahami dan memiliki kemampuan untuk melaksanakan nilainilai demokrasi sebagaimana adanya, baik pada tataran kebijakan, tataran implementasi maupun pada tataran kultural yang mensyaratkan adanya mekanisme check and balances (saling kontrol dan saling mengimbangi) antara pemerintah dengan yang 
diperintah. Harus dipahami bahwa prinsip demokrasi yang utama adalah proses yang sistemik yang melibatkan berbagai potensi yang saling berpengaruh serta mempunyai kekuatan yang seimbang.

Dengan kata lain, demokrasi membutuhkan suatu keseimbangan kekuatan yang karenanya tidak terjadi dominasi elit terhadap rakyat. Sehingga berbagai kebijakan negara dapat mereprsentasikan semua potensi yang ada pada rakyat. Hal ini juga menunjukkan bahwa koridor demokrasi adalah kesetaraan yang dicerminkan dari sikap dan prilaku yang memandang suatu perbedaan sebagai kekayaan demokrasi.

Perbedaan tidak harus ditabukan, sementara ketidaksepakatan harus dianggap sebagi -bunga-bunga menuju kematangan politik (political maturity). Untuk mencapai koridor demikian, manajemen pemerintahan dituntut untuk dapat memfasilitasi berlangsungnya mekanisme ekonomi, politik dan sosial budaya yang sistemik. Sehingga akan terjadi penguatan politik rakyat, yang juga dapat diartikan sebagai penguatan ekonomi, sosial sekaligus budaya rakyat, sebgai dasar dari model pemerintahan yang demokratis yang berarti juga penguatan terhadap otonomi daerah. Pemahaman demikian karena dari beberapa pandangan dikemukakan bahwa demokrasi dapat dijadikan sarana bagi terwujudnya tujuan bernegara dan berpemerintahan, yaitu tercapainya kesejahteraan rakyat. Oleh sebab itu manajemen pemerintahan khususnya di daerah harus memiliki kemampuan untuk menyerap kepentingan-kepentingan publik, yang kemudian diekspresikann dan dimanifestasikan dalam kehidupan politik pemerintahan dan pembangunan.

\section{Perubahan Manajemen Pemerintahan di Daerah}

Tuntutan terhadap dilaksanakannya good governance dalam manajemen pemerintahan tidak dapat dilepaskan dari terbukanya informasi dan meluasnya wacana 
demokratisasi dalam kehidupan rakyat dan pemerintah. Disamping tuntutan terhadap keadilan, ketertiban dan kesejahteraan, transparansi perimbangan keuangan dalam hubungan pusat dan daerah dan demokratisasi yang memenuhi ukuran standar hak asasi manusia. Hal ini disebabkan karena pelaksanaan otonomi membutuhkan manajemen pemerintahan daerah yang beroirentasi pada good governance, demokratis dan memahami lingkungan sebagaimana darah istimewa Aceh dan Propinsi Papua.

Terlepas dari model otonomi di atas, manajemen pemerintahan daerah otonom harus tetap berada dalam koridor UU tentang Pemerintahan Daerah dan melaksanakan fungsi kepemerintahannya dalam kerangka otonomi daerah. Untuk itu manajemen pemerintahan di daerah otonom harus memahami secara utuh makna dan implementasi otonomi daerahnya. Pemahaman yang dimaksud adalah: Pertama, Daerah berhak atas tambahan sumber keuangan lyang memadai dalam pembiayaan pembangunan yang didapat dari Pendapatan Asli Daerah Sendiri (PADS) dan bagi hasil atas pajak dan sumber-sumber keuangan yang didapat dari daerah. Daerah berhak atas pasokan aparatur pemerintahan yang memiliki kualifikasi professional dan accountable untuk dapat mendinamisasikan pembangunan di daerah. Hal tersebut menunjukkan bahwa Otonomi Daerah yang diharapkan adalah otonomi daerah yang bertanggung jawab karena dilakukan oleh aparatur yang professional, berdisplin dan berorientasi pada target untuk meningkatkan kesejahteraan rakyat.

Kedua, Daerah berhak untuk memilliki kewenangan atas kelembagaan, kebijakan dan keuangan daerah. Dengan otoritas tersebut, daerah dapat mengambil inisiatif sendiri sesuai dengan tuntutan kepentingan di daerah, baik menyangkut perlengkapan, keorganisasian maupun pembiayaan. Kewenangan di atas merupakan hak daerah yang merupakan implementasi dari diberlakukannya otonomi yaitu : (a) Pembaharu yang potensial di daerah, sehingga dapat memasuki dan mengikuti proses 
pembangunan, (b) Pembuatan keputusan dan kebijakan daerah akan semakin cepat, sehubungan pendeknya jalur birokrasi yang harus dilalui, (c) Pengawasan terhadap aparat akan semakin mudah untuk dilaksanakan baik dilakukan secara personal, maupun dilaksanakan secara organisatoris; dan (d) Dapat mengeliminasi dan menyeragamkan masalah melalui aturan-aturan yang dikeluarkan oleh pusat, hal ini harus disesuaikan dengan kebutuhan daerah.

Ketiga, Implementasi kebijakan dan perubahan manajemen pemerintahan di daerah merupakan proses transformasi organisasi dari bentuk sentralistis ke bentuk yang lebih desentralistis. Proses transformasi organisasi manajemen pemerintahan ini mencakup (1) -reframing yaitu pergeseran konsepsi visi dan misi serta pengukuran keberhasilan manajemen pemerintahan, (2) -restructuring yaitu perubahan struktur, -reengineering proses kerja, alokasi sumber daya dan sebagainya, (3) -revitalization yaitu merubah kinerja pelayanan sesuai dengan kebutuhan masyarakat dan teknologi, dan (4) -renewal yaitu memperbaharui sistem penggajian, promosi, pengembangan karir dan organisasi. Jadi proses pemberian otonomi daerah kepada daerah harus dilihat dengan proses transformasi organisasi dan keberhasilan daerah atas efektivitas dan efisiensi proses berpemerintahan.

Keempat, dilihat secara teoritis sistem pemerintahan daerah yang berlaku di Indonesia termasuk tipe sistem perfektoral terintegrasi (integrated perfectoral system), yaitu terdapat integrasi dalam dua hal. Terdapat integrasi antara batas-batas daerah otonom dengan batas-batas wilayah adminstratif di bawah yurisdiksi pemerintah pusat, khususnya pada pemerintah propinsi yang merupakan wakil pemerintah dan memiliki kewenangan lintas kota dan kabupaten.

Kewenangan pemerintah propinsi yang melintas ini belum memiliki ramburambunya, mengenai yang boleh dan yang tidak mencampuri kewenangan daerah 
sehingga akan dapat membingungkan daerah, disamping itu juga terdapat integrasi dengan batas-batas wilayah administratif di bawah yurisdiksi pemerintah propinsi, contohnya batas-batas daerah kota dan kabupaten adalah sama dengan batas-batas instansi vertikal yang ada didaerahnya. Hal itu berarti Pemerintahan Daerah Kota dan Kabupaten (eksekutif maupun legislatif daerah) harus membuat peraturan darah baru atau merevisi peraturan daerah yang sudah tidak sesuai dengan peraturan-peraturan yang lebih atas.

Kelima, Implementasi kebijakan desentralisasi dan otonomi di Indonesia, khususnya dengan penekanan pada daerah menghadapi berbagai masalah, antara lain : (a) masih adanya kewenangan yang rancu antara urusan pemerintahan pusat, propinsi dan kabupaten/kota, antara lain menyangkut urusan sejenis, misalkan masalah tanah dan masalah agama. Sampai sejauh ini masalah pertanahan dan keagamaan belum diserahkan ke daerah akibatnya terjadi dualisme dalam manajemen pertanahan dan keagamaan di daerah. (b) adanya keterbatasan kemampuan keuangan daerah karena potensi PAD (Pendapatan Asli Daerah) yang kecil, sementara bantuan keuangan dari Pusat umumnya sudah ditentukan penggunaannya (specific grants) sementara Dana Alokasi Umum (DAU) dan Dana Alokasi Khusus (DAK) relatif terbatas sesuai dengan kriteria yang telah ditentukan pusat. Adapun dana perimbangan sangat bergantung pada potensi yang dimiliki daerah tersebut.

Hal ini berakibat Pemerintah Kota/Kabupaten tidak leluasa dalam menyusun anggaran Pendapatan dan Belanja Daerahnya sendiri. (c) kemampuan administrasi Kota/Kabupaten yang rendah karena banyak faktor yang tidak mendukung seperti kualitas sumber daya manusia yang kurang memadai, struktur organisasi yang rigid, sistem dan prosedur yang berbelit-bellit, serta budaya kerja yang rendah. Di lain pihak, cepatnya perubahan sosial ekonomi masyarakat telah meningkatkan kebutuhan 
terhadap pelayanan masyarakat yang lebih efisien, reliable dan predicable. Akibatnya, pelayanan masyarakat yang diberikan semakin jauh dari harapan masyarakat sebagai pengguna jasa pemerintahan daerah. Untuk itu, perubahan format pemerintahan daerah harus dilakukan, antara lain melalui perubahan orientasi yang semula sebagai pelaku diubah menjadi pengarah (steering than rowing), dengan kata lain prinsip yang harus dipegang oleh manajemen pemerintahan daerah adalah sedapat mungkin tidak mengintervensi kepentingan masyarakat dan membiarkan inisiatif masyarakat berkembang (society initiatives wherever possible and state intervention wherever necessary).

Kelima, penyerahan urusan-urusan pemerintahan kepada daerah seharusnya berdampak strategis terutama terhadap ruang lingkup otonomi yang bertambah luas dan visi tentang otonomi yang disesuaikan dengan potensi daerah. Akan tetapi meskipun hampir semua urusan-urusan pemerintahan sudah diserahkan kepada daerah, dalam realitanya masih ada keputusan-keputusan anggaran, kepegawaian dan perlengkapan untuk keperluan urusan-urusan pemerintahan yang sebenarnya sudah diserahkan kepada daerah masih harus dibuat di tingkat pusat atau propinsi.

Hal itu disebabkan belum seragamnya persepsi tentang visi dan strategi pelaksanaan kebijaksanaan desentalisasi dan otonomi di antara berbagai instansi pemerintahan (Pusat, Propinsi, Kota/kabupaten). Khususnya tentang perubahan pengelolaan berbagai urusan pemerintahan yang telah diserahkan atau yang harus dserahkan kepada daerah. Oleh sebab itu, sistem berpemerintahan yang masih beroreintasi pada pendekatan sentralistis sektoral hendaknya diubah dan direposisi menjadi pendekatan desentralisasi yang terintegrasi. Hal ini membutuhkan sinergitas antar instansi pemerintahan. 
Harus dipahami bahwa mekanisme pemerintahan yang diharapkan oleh rakyat adalah mekanisme pemerintahan yang dapat mencerminkan kesetaraan yang dicerminkan dengan sistem yang transparan, berkemampuan menyerap dan mengakomodosi aspirasi serta berkemampuan mengoperasionalkan aspirasi rakyat tersebut dalam kebijakan pemerintah. Dengan demikian manajemen pemerintahan daerah harus merubah paradigma lama yang feodal-tradisional ke paradigma yang modern dan demokratis dengan penekanan pada pembangunan koordinasi internal organisasi pemerintah dan partisipasi efektif rakyat.

Dengan kata lain manajemen pemerintahan daerah harus bertindak sebagai pengarah daripada sebagai pelaksana (steering than rowing) sehingga pemerintah daerah dapat mengakomodasikan dan mengaktualisasikan berbagai potensi dan aspirasi yang ada dalam masyarakat, melalui program-program yang telah ditentukan bersama antara rakyat dengan pemerintah. Program-program tersebut antara lain meliputi prinsip pelayanan berikut:

Pertama, prinsip pelayanan. Prinsip pelayanan memerlukan semangat untuk melayani masyarakat (a spirit of public services) dan menjadi mitra masyarakat (partner of society) atau melakukan kerjasama dengan masyarakat (co-production). Hal tersebut memerlukan perubahan prilaku manajemen pemerintahan yang dilakukan melalui pemberdayaan kode etik (code of ethical conducts) yang didasarkan pada dukungan lingkungan (enabling strategy) yang diterjemahkan ke dalam standar tingkah laku yang dapat diterima umum dan dijadikan acuan prilaku birokrasi pemerintah. Di samping itu, manajemen pemerintahan ini dituntut untuk bersifat transparan dan terbuka serta memiliki akuntabilitas (accountable) pada setiap kebijakannya. Memahami konsep pelayanan, berarti memahami bahwa pelayanan membutuhkan semangat pengabdian yang mengutamakan efisiensi yang dimanifestasikan antara lain 
dalam prilaku -melayani, bukan dilayani, -mendorong bukan menghambat, -mempermudah bukan mempersulit, -sederhana bukan berbelit-belit, -terbuka untuk setiap orang, bukan hanya untuk segelintir orang .

Kedua, prinsip pemberdayaan memungkinkan inisiatif dan kreatifitas rakyat berkembang, sehingga dapat menyalurkan potensi-potensi yang dimilikinya. Prinsip pemberdayaan ini perlu dilakukan melalui tindakan-tindakan pemerintah untuk mengurangi hambatan dan kendala-kendala bagi kreativitas dan partispasi masyarakat. Selain itu perlu membuat ruang publik terpadu (integrated of public sphere) bagi rakyat, sehingga memungkinkan terjadinya interaksi positif antara rakyat dengan pemerintah. Prinsip pemberdayaan ini pun berarti perluasan akses pelayanan untuk menunjang berbagai kegiatan sosial ekonomi masyarakat dan memperpendek birokrasi. Dengan demikian, pemberdayaan juga menyangkut pada pengembangan program yang lebih memberikan kesempatan kepada proses belajar masyarakat (social learning process) dalam memanfaatkan dan mendayagunakan sumber daya produktif daerah yang tersedia, sehingga memiliki nilai tambah guna meningkatkan kesejahteraan rakyat daerah.

Ketiga, prinsip partisipasi, melalui prinsip ini masyarakat diikutsertakan dalam proses menghasilkan public goods and services, dengan mengembangkan pola kemitraan dan kebersamaan antara birokrasi dengan rakyat. Untuk itulah kemampuan masyarakat harus diperkuat (empowering rather than serving), melalui pemberian kepercayaan kepada rakyat untuk berperan aktif dalam pembangunan daerah. Prinsip partisipasi juga selalu dikaitkan dengan konsep pemberdayaan (empowering) dalam rangka menyusun kerangka kemitraan dalam manajemen pembangunan, mendesentralisasikan proses pengambilan keputusan, serta menumbuhkan keswadayaan masyarakat. Prinsip partisipasi ini juga menekankan pada anggapan 
bahwa fokus pembangunan yang hakiki adalah peningkatan kapasitas perseorangan dan kelembagaan (capacity building) dengan tidak mengabaikan penyebaran informasi mengenai berbagai potensi dan peluang pembangunan di daerah yang masih terbuka bagi rakyat daerah.

Keempat, prinsip pembangunan. Privatisasi dan dunia usaha menjadi ujung tombak dalam prinsip pembangunan ini. Dalam privatisasi, maka kemitraan menjadi penting dalam pengembangan dan modernisasi dunia usaha terutama antara usaha kecil dan menengah, kedua jenis usaha ini diarahkan pada peningkatan mutu dan efisiensi serta produktivitas. Terutama dalam pengembangan dan penguasaan teknologi dan manajemen produksi, pemasaran dan informasi.

Dalam mengembangkan kemitraan dunia usaha yang saling menguntungkan antara usaha besar, menengah dan kecil tersebut, pranan manajemen pemerintah ditujukan pada arah pertumbuhan yang serasi, yaitu melalui penciptaan iklim usaha dan kondisi lingkungan bisnis yang kondusif bagi tumbuhnya kemitraan dimaksud, yang meliputi produksi, pemasaran dan jasa.

Melalui penciptaan berbagai kebijakan dan/atau pearngkat peratuan daerah yang sesuai. Upaya menumbuhkan kemitraan inipun meliputi upaya pengintegrasian usaha kecil kedalam sektor modern dalam ekonomi lokal, regional dan nasional,serta mendorong proses pertumbuhannya.

\section{Esensi Manajemen Pemerintahan}

1. Pemerintah dengan organisasi yang kecil, cepat dan murah merupakan pemerintah yang baik

Pemerintah pada saat ini telah berkembang menjadi sangat besar dengan rentangan sayap-sayap birokrasi yang lebih banyak membutuhkan sumberdaya, 
akan tetapi tidak mampu membuat perbaikan yang signifikan di bidang pelayanan. Hal inil yang antara lain menyebabkan munculnya gagasan auto pilot yang dapat diartikan pemerintahan dapat berjalan sendiri. Sementara diketahui bahwa persoalan pemerintahan akan semakin banyak, pemerintah membutuhkan kerja yang efektif dan efisien. Oleh karena itu yang dibutuhkan adalah suatu model pemerintahan yang kecil dengan sayap birokrasi yang pendek, sehingga mempercepat dan mempermudah pelayanan kepada rakyat.

2. Pemerintah berorientasi pada manajemen privat/swastanisasi

Salah satu cara agar pemerintah yang kecil, cepat dan murah dapat tercapai adalah melalui bekerja secara professional dan kolektifitas serta privatisasi, yaitu suatu proses penyerahan sebagian kewenangan kepada pihak-pihak lain/privat yang didasarkan profesionalisasi untuk memberikan pelayanan dengan biaya lebih efisien kepada konsumen, hal ini diperkirakan akan berdampak pada pengurangan pengeluaran pemerintah disampng mengurangi korupsi. Walaupun demikian diawal proses pemberian kewenangan kepada pihak-pihak lain tesebut/privat akan menciptakan peluang untuk korupsi, seperti pada proses penentuan harga jual jasa atau produk yang diberikan oleh pemerintah. Dalam tindakan kolektif ini, perjanjian, pengaturan proses penawaran serta dalam penilaian kinerja punlik didasarkan pada sistem kontrak, sehingga pihak-pihak yang bergabung dalam kolektivitas ini dapat bertanggung jawab pada bidang/unit kerjanya masing-masing.

3. Pemimpin harus bersifat komersial dalam tindakannya Dengan mengadopsi prinsip-prinsip dasar diharapkan pemerintah akan mampu mengelola sektor publik lebih efisien dan efektif. Praktek ini antara lain ditunjukkan melalui profesionalisme dalam pelayanan, sehingga aktifitas 
professional itu akan dihargai bagi pengguna jasa pemerintah dan aset-aset pemerintah, artinya produk dan jasa pemerintah mempunyai ukuran keuangannya sendiri.

Dengan tindakan yang professional dalam konsep berpikir privat, pemerintah dimungkinkan untuk mengembangkan lebih luas aturan, juga pencabutan ketentuan yang langsung atas suat barang dan jasa. Untuk meyakinkan bahwa kontark dipahami dan berkualitas.

4. Pemimpin perlu mendesentralisasikan kekuasaannya

Pandangan tradisional dari desentralisasi berfokus pada dimensi territorial yaitu seberapa besar kekuasaan dan otoritas harus diberikan oleh pemerintah ke instansi pemerintah dibawahnya; ketika pusat mendesentralisasikan kekuasaan dan memberi kekuasaan yang lebih besar dalam pengambilan keputusan oleh manajer di bawahnya, maka hal itu akan memungkinkan pusat lebih fleksibel dalam upaya mencapai tujuannya dan mengarahkan pengambilan keputusan ke pihak-pihak yang akan terpengaruh.

Walaupun demikian, pada permulaan desentralisasi harus pula dipertimbangkan asumsi-asumsi bahwa dalam efisiensi yang diperoleh terkadang melupakan masalah yang mungkin timbul. Oleh sebab itu pengendalian harus disesuaikan untuk memberi keyakinan bahwa desentralisasi kekuasaan tesebut tidak melewati batas. Perlu diketahui bahwa pemberian kekuasaan akan membuka peluang kepada individu untuk memanfaatkan sumberdaya untuk publik bagi keuntungan pribadi atau keuntungan orang lain. Desentralisasi bukanlah proses satu arah yang secara mudah memberikan kekuasaan, tetapi proses ini melibatkan suatu orientasi kembali dari pusat untuk mengatur kembali dan memodifikasi aturan yang ada. Pemerintah berkurang 
keterlibatannya dalam masalah pelayanan dan lebih perhatian pada kebijakan menyeluruh kepada institusi yang lebih rendah atau manajer kota/kabupaten untuk menentukan dan mencapai tujuannya.

\section{Debirokrasi}

Pemerintah pada umumnya memperoleh kritik pada panjangnya birokrasi yang tidak sesuai fungsinya. Ketidaksesuaian ini secara umum karena organisasi pemerintah berjalan lamban, tide up red tape, membuat jarak dengan yang seharusnya dilayani, pembagian hierarki yang terlalu banyak, tidak simpatik terhadap klien dan kurang fleksibel. Korupsi akan tumbuh subur dalam lingkungan dimana akuntabilitas hanya untuk di dalam dan di atas, tanpa ada laporan yang rinci dari publik sementara in-efisiensi dan inefektifitas akan semakin berkembang. Keputusan bisa dengan cepat ditelusuri dalam birokrasi yang membingungkan dengan menelusuri pembayaran yang tidak resmi.

Ketidaksesuaian fungsi dalam birokrasi dilaksanakan melalui -capacity building institutional strengthening, steamlining dan re-engineering digunakan untuk menggambarkan usaha yang dilakukan untuk membangun kapasitas manajemen pada sektor pemerintah. Sektor swasta telah menjadi sumber acuan utama dalam inovasi manajemen untuk memperbaiki kinerja, karena sektor swasta merupakan gambaran dari kedisiplinan pasar. Jika teknikteknik swasta yang responsif terhadap permintaan pasar tersebut ditransfer ke sektor publik, maka diharapkan secara bersamaan akan ada perbaikan kinerja pada sektor tersebut. Hal ini kurang lebih disebabkan karena akan terjadi inovasi-inovasi seperti penilaian kinerja, pedoman dan manajemen berdasar kualitas (TQM) yang harus diterapkan pada sektor pemerintah. 
6. Akuntabilitas (Accountability)

Akuntabilitas merupakan acuan utama bagi manajemen pemerintahan dengan variasi gambaran yang baik untuk model dalam pemerintahan dengan pengaturan yang baik (good governance).

7. Pemimpin harus bertindak sebagai professional

Hal itu disebabkan karena masalah pelayanan dan penyelesaian hambatan membutuhkan kerja manajerial yang lebih professional yang meletakkan kepuasan klien/konsumen sebagai acuan utama dari keberadaan mereka di sektor publik. Dipahami bahwa manajemen pemerintahan yang professional akan menyebabkan berbagai kebijakan yang dilaksanakan mudah diterima dan didayagunakan oleh masyarakat sebagai pelaksana dan pengelola, sehingga acceptable, accountable, profitable, sustainable dan replicable.

8. Visioner dan rencana yang jelas

Manajemen pemerintahan dalam pengalokasian program-program pembangunan harus tepat sasaran dan sesuai dengan aspirasi masyarakat yang berkembang. Pengalokasian program yang tepat sasaran tersebut akan menyebabkan terjadinya proses yang berkesinambungan untuk mencapai visi dan misi daerah yang telah ditentukan (well targeted).

9. Distribusikan sumber-sumber potensi

Bahwa program-program pemerintah harus tampak dan transparan dalam penyebaran dan pendistribusian dana pembangunan, sehingga efisiensi dan efektifitas pembangunan tetap dapat dipertahankan serta mencegah kebocorankebocoran dana pembangunan (delivering mechanism). Manajemen pemerintahan, walaupun merupakan kerja manajer akan tetapi ia akan melibatkan seluruh komponen pemerintah yang ada. Dengan demikian 
tampaknya pengkajian ulang atas keberadaan lembaga-lembaga pemerintahan yang ada pada saat ini perlu dilakukan, sehingga kecepatan dan ketepatan pelayanan dapat dicapai. Hal ini tentunya menuntut bahwa seorang pemimpin seharusnya adalah orang yang cerdas, karena intelektualitaslah yang menentukan keberhasilan mewujudkan arah dan tujuan manajemen.

\section{Penutup}

Berdasarkan pemikiran di atas, maka dapat disimpulkan bahwa manajemen pemerintahan dituntut untuk merubah paradigma yang feodal tradisional ke paradigma modern demokratis. Hal itu berkaitan dengan tuntutan globalisasi yang dicerminkan melalui pasar global, lingkungan global dan kepolitikan global. Dalam kerangka itu, maka manajemen pemerintahan harus memiliki kemampuan untuk menyelenggarakan pemerintahan dalam konsep good governance, demokratis dan memahami lingkungan.

Ketiga aspek ini harus dijalankan secara bersamaan, sehingga pelayanan, pemberdayaan, partisipasi dan pembangunan dapat dilaksanakan untuk mewujudkan otonomi daerah yang selanjutnya menumbuhkembangkan inisiatif dan kreativitas rakyat. Di samping meningkatkan kinerja pemerintahan, melalui harmonisasi koordinasi internal pemerintahan, transparansi, akuntabilitas dan keterbukaan serta penegakkan sanksi-sanksi hukum bagi pelanggar-pelanggar peraturan yang telah disepakati merupakan keharusan bagi pemerintah untuk menerjemahkan kehendak publik. Publikernisasi pemerintahan melalui re-engineering institusi-institusi ekonomi, politik dan sosial yang ada di daerah sesuai perkembangan informasi dan teknologi juga merupakan proses berpemerintahan.

Di sisi lain memodernisasi melalui re-engineering (merekayasa) institusi publik maupun insitusi swasta mengharuskan manajemen pemerintahan mengkoreksi berbagai kebijakan yang menghambat serta menyusun ataupun merevisi peraturan-peraturan 
yang diselaraskan dengan ukuran-ukuran demokrasi dan lingkungan. Serta memfasilitasi ruang public guna mengakomodir aspirasi dan kepentingan rakyat, disamping menyusun jaringan kerja untuk produk unggulan daerah dalam pasar global dan meningkatkan kinerja pemerintahan.

Beberapa kesimpulan di atas, menunjukkan bahwa perubahan yang mendasar dalam tampilan manajemen pemerintahan menjadi kebutuhan yang mendesak guna merealisasikan otonomi daerah. Jika hal ini tidak dianggap dengan bersungguhsungguh untuk dirubah, maka kemungkinan terjadinya pengulangan krisis kepercayaan terhadap kinerja pemerintah akan sulit untuk dihindarkan lagi.

\section{Daftar Pustaka}

Almond, Gabriel and James S Colemann, 1960. The Politics of the Developong Areas. New York: The Princenton University Press

Almond, Gabriel and Sidney Verba. 1965. The Civic Culture. Boston: Little Brown

Barzelay, Michael. 1992. Breaking Through Bureacracy. University of Berkeley

Dahl, Robert, A, 1982. Analisa Politik Modern. Jakarta: PT Gramedia

Dye, Thomas R. 1987. Public Policy. New York-Toronto

Huntington, Samuel P. 1984. No Easy Choice: Political Parisipation in Developing Countries. Cambride Mass: Harvard Uiversity Press

Huntington, Samuel Pll. 1997. Gelombang Demokrasi Ketiga, PT Pustakan Utama Grafity: Jakarta

Hoessein, Bhyenyamin. 1996. -Memutar Roda Desentralisasi dari Efisiensi ke Demokrasi dalam Prisma No 4 Jakarta

Indonesia Corruption Watch (ICW). 1999/ Akuntabilitas dan Korupsi di Melanesia: Mengevaluasi aturan Ombudsman dan Kode Etik Kepemimpinan, hal 1-3

Ingraham, Patricia W, Romzek, Barbara S and Associates. 1994, New Paradigms for Governement, Issues for the Changing Public Service, Jossey Bass Publisher: San Fransisco 
Koehler, Jerry W, Pankowski, Joseph M. 1997. Tranformational Leadership in Governent, Delray Beach Florida: St Lucia Press

Kooiman, Jan (ed) 1993. Modern Governance, New Governent-Societly Inetractions, Sage Publication Londo, New Bury Park, New Delhi

Kristiadi J.B. 1997. Perspektif Administrasi Publik Menghadapi Tantangan Abad 21 dalam Jurnal Administrasi dan Pembangunan, PP Persadi Jakarta

Manan, Bagir. 1999. Dasar dan Dimensi Politik Otonomi dan UUI No 22 Tahun 1999, Jurusan Ilmu Pemerintahan, FISIP/UNPAD

Redjo, Samugyo Ibnu, 1998. Visi dan Misi Metropolitan Bandung 2020. Pemerintah Daerah Kotamadya DT II Bandung

Redjo, Samugyo Ibnu. 1993. Pembangunan Politik di Indonesia: Kasus Partai-Partai Politik.

Dalam Amir Santos dan Riza Sihbudi (eds) Politik, Kebijakan dan Pembangunan. Jakarta: Grafika Lestari

Schrode, William, A, Voich, Dan JR. 1974. Organization and Management Basic System Concepts, Floridan State University: Florida

Mc Andrews, Colin. 1995. Struktur Pemerintahan di Indonesia. Dallam Colin Mc Andrewsl dan Ichlasul Amal: Hubungan Pasat dan Daerah Dalam Pembangunan. Jakarta.

Osborne David and Tod Gaebler. 1995. Mewirausahakan Birokrasi (terjemahan) Jakarta :PT Pustaka Binaman Pressindo

Osborne David and Peter Plastrik. 1997. Banishing Bureaucracy. New York: Addison Wesley Publishing Company

Suryo, Djoko. 1991. Feodalisme: Timur dalam Prisma No 8, 